\title{
УAK 658.6
}

Н. О. Небаба,

к. е. н., Аоцент кафедри економіки та соціально-трудових відносин,

Університет митної справи та фінансів

I. М. Аемяшкін, магістрант, Університет митної справи та фінансів

DOI: $10.32702 / 2306-6792.2019 .5 .78$

\section{РОЗРОБКА ПРОЕКТУ АУАИТУ ПЕРСОНААУ ЯК IHСТРУМЕНТУ HR-АНААІТИКИ В МІЖНАРОАНИХ КОМПАНІЯХ}

\author{
N. Nebaba, \\ Ph.D. in Economics, Associate Professor of the Department of Economics \\ and Socio-Labor Relations, University of Customs and Finance \\ I. Demyshkin, \\ magistrate, University of Customs and Finance
}

\section{PROJECT DEVELOPMENT FOR PERSONNEL AUDIENCE AS A TOOL FOR HR-ANALYST IN INTERNATIONAL COMPANIES}

На основі здійсненого дослідження, узагальнивши теоретичні положення аудиту персоналу міжнародної компанії, визначено його задачі, об'єкти оцінки, методи впровадження у систему управління персоналом організації вцілому. Розглянуто переваги та недоліки методів впровадження аудиту у систему управління персоналом міжнародної компанії. Аосліджено проблеми впровадження аудиту персоналу та розглянуто способи їх нівелювання. Визначено, що аудит персоналу повинен зАійснюватися в декілька етапів: етап підготовки, збору інформації, етап обробки отриманих даних та заключний етап. Складено мережевий графік реалізації розробленого проекту аудиту персоналу підприємства. Аоведено, що впровадження проекту аудиту персоналу у міжнародній компанії підвищить відповіАальність працівників, дозволить оцінити результативність Аіяльності персоналу, дозволить виявити слабкі місця та покращити всі кадрові процеси, удосконалити систему управління персоналом та міжнародної компанії вцілому.

On the basis of the performed scientific research, summarizing the theoretical provisions of the personnel audit, its tasks, objects of evaluation, methods of introduction of personnel audit in the system of personnel management and organization in general were determined. The advantages and disadvantages of the above-mentioned methods are considered. The problems of introduction of personnel audit and the ways of their leveling are considered. It has been determined that personnel audit should be carried out in several stages: the stage of preparation, information gathering, the processing stage of the received data and the final stage. The network schedule of implementation of the developed personnel audit project has been completed. It is proved that introduction of the project of personnel audit at the enterprise will increase the responsibility of employees, will allow to evaluate the effectiveness of the personnel, will identify weaknesses and improve all personnel processes, improve the system of personnel management and organization in general. Established that human resources audit is a powerful tool that allows the management of an international company to identify problems with its management system, and allows you to provide recommendations for improving it. The system of personnel management of an international company was analyzed in order to eliminate such negative tendencies in activity as: turnover of personnel, reduction of average number of employees. It is proposed to introduce a system of personnel audit in the activities of an international company. Recommendations were given, recommended areas of personnel audit in an international company were indicated. It is determined that the developed project of audit of the personnel of the international company will allow: to identify the problem areas in its staffing, improve the microclimate within the company; improve the human resources management system; management to respond timely to problems with personnel. It is determined that the implementation of the audit of the international company personnel is envisaged in several stages, namely: preparation for audit, analysis of key indicators, collection, compilation and processing of information, drawing up a report and reporting on recommendations to the management of an international company.

Ключові слова: аудит, персонал, міжнародна компаніл, НR-аналітика, проект, управління, система.

Key words: audit, staff, international company, HR-analytics, project, management, system.

\section{АКТУАЛЬНІСТЬ ТЕМИ}

В останні десятиліття, в зв'язку зі зростанням розуміння ролі людини в організації діяльності підприємств різних галузей і форм влас- ності, питання аудиту персоналу висуваються на передній план. Перед сучасним керівником будь-якої організації стоїть задача не тільки пошуку та підбору співробітників, а і питання 
підвищення продуктивності праці, оптимізації структури компанії, підвищення результативності діяльності персоналу. Без аналітичних досліджень і обробки даних складно приймати обгрунтовані рішення, поліпшувати показники і ефективність бізнесу. Вимірюючи і аналізуючи ключові параметри, HR-підрозділи можуть приймати ділові рішення, засновані на фактах, використовувати точні цифри при розробці бізнес-кейсів і формуванні заявок на ресурси. Крім того, директора служби персоналу можуть своєчасно інформувати топ-менеджерів про стан людських ресурсів, аргументувати ефективність HR-служби. Одним із найбільш широко застосовуваних на сучасному підприємстві інструментів HRаналітики є аудит персоналу. Він дозволяє оцінити ступінь ефективності і повноти використання трудового потенціалу. 3 огляду на науково-практичну актуальність теми на сьогодні основною проблемою є розуміння необхідності впровадження аудиту персоналу підприємства, його значення для ефективного функціонування підприємства. Тому проектування системи аудиту на підприємстві є необхідним заходом, адже забезпечить його конкурентоспроможність у майбутньому.

\section{АНАЛІЗ ОСТАННІХ ДОСЛІДЖЕНЬ І ПУБЛІКАЦІЙ}

Значний внесок у розроблення та аналіз теоретичних, методологічних і практичних засад аудиту персоналу в міжнародних компаніях здійснили такі вітчизняні та зарубіжні науковці: О.С. Аебединська [2], С.В. Назайкинский

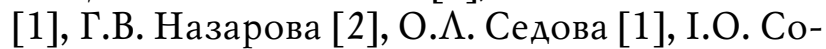
вершенна [3], I.В. Трофимов [4], Ф.Н. Филина [5], Є.М. Фріман [6], С.М. Хмелевський [7] та iншi.

\section{ПОСТАНОВКА ЗАВДАННЯ}

Метою статті є дослідження аудиту персоналу як інструменту HR-аналітики в міжнародних компаніях, його етапів та задач, а також аналіз підходів та проблем впровадження такого аудиту.

\section{ВИКЛАД ОСНОВНОГО МАТЕРІАЛУ ДОСЛІДЖЕННЯ}

Поняття аудиту персоналу як послуги для нашої країни досить нове. Він знаходиться на початковому розвитку як загальноукраїнському, так і регіональному. В якості реалізації внутрі-
Таблиця 1. Класифікація задач аудиту персоналу у міжнародних компаніях

\begin{tabular}{|c|c|}
\hline Об'єкти оцінки & Задачі аудиту \\
\hline $\begin{array}{l}\text { анування } \\
\text { рсоналу }\end{array}$ & $\begin{array}{l}\text { оцінка наявних ресурсів; } \\
\text { вивчення потреби в персоналі; } \\
\text { перевірка планів по персоналу на повноту, обгрунтованість } \\
\text { і можливість реалізації }\end{array}$ \\
\hline $\begin{array}{l}\text { користання } \\
\text { рсоналу }\end{array}$ & $\begin{array}{l}\text { вивчення кількісного складу персоналу організації; } \\
\text { розробка і координація заходів для усунення негативних } \\
\text { відхилень }\end{array}$ \\
\hline $\begin{array}{l}\text { ідбір } \\
\text { рсоналу }\end{array}$ & $\begin{array}{l}\text { оцінка наявних заходів, які застосовуються при відборі } \\
\text { персоналу; } \\
\text { оцінка результативності процедур; } \\
\text { оцінка взаємодії організації із зовнішнім службами } \\
\text { працевлаштування, навчальними закладами } \\
\end{array}$ \\
\hline $\begin{array}{l}\text { цінка } \\
\text { рсоналу }\end{array}$ & $\begin{array}{l}\text { аналіз використовуваних форм оцінки персоналу; } \\
\text { вивчення строків проведення оцінки, її періодичність; } \\
\text { аналіз результатів проведення оцінки }\end{array}$ \\
\hline $\begin{array}{l}\text { даптація } \\
\text { ерсоналу }\end{array}$ & $\begin{array}{l}\text { вивчення і оцінка основних методів адаптації персоналу та } \\
\text { оцінка їх ефективності; } \\
\text { виявлення основних причин, що виникають в процесі } \\
\text { адаптації }\end{array}$ \\
\hline $\begin{array}{l}\text { авчання } \\
\text { ерсоналу }\end{array}$ & $\begin{array}{l}\text { аналіз використовуваних форм навчання; } \\
\text { вивчення змісту і тривалості навчання; } \\
\text { оцінка персоналу, що пройшов навчання; } \\
\text { оцінка ефективності навчання на основі наявних фактичних } \\
\text { результатів }\end{array}$ \\
\hline $\begin{array}{l}\text { осування } \\
\text { соналу }\end{array}$ & $\begin{array}{l}\text { вивчення системи просування персоналу в організації; } \\
\text { аналіз заміщення посад; } \\
\text { оцінка результативності методів планування кар'єри }\end{array}$ \\
\hline
\end{tabular}

жерело: складено авторами на основі $[4 ; 6 ; 7]$.

шнього аудиту організації виступає концепція аудиту, яка дозволить здійснювати моніторинг досягнення цілей. Аудит характеризується відмітними особливостями, що, в свою чергу, обумовлює ряд особливих вимог до його організації, які створюють певне коло проблем. $\mathrm{O}_{\mathrm{A}-}$ нією з головних проблем при проведенні аудиту $€$ пошук і збір інформації. Оскільки на інформацію, що стосується процесу управління персоналом, нерідко впливають суб'єктивні фактори, персонал вважається найбільш важкокерованим ресурсом. Не менш значущою проблемою вважається знижена трудова мотивація, підвищена плинність кадрів або тривалий процес адаптації нових співробітників у міжнародній компанії. Проблемою впровадження аудиту персоналу є відсутність доступних для користувачів теоретичних розробок щодо застосування технології аудиту в сфері оцінки управлінського персоналу. Ситуація, що склалася в цій сфері управлінської діяльності, може бути охарактеризована як етап вироблення концептуальних уявлень в теорії і інтуїтивний пошук ефективних рішень 3 кадрових проблем на практиці. Не менш важливою проблемою аудиту є проблема сприйняття нової системи. Введення системи аудиту в ряді випадків викликає у працівників стан психологічного дискомфорту, оскільки, на їх погляд, може призвести до посилення контрольних заходів і підвищеної прозорості, що не завжди вітається колективом. Основною метою системи аудиту є координація процесу управлі- 
Таблиця 2. Підходи впровадження аудиту персоналу в міжнародних компаніях

\begin{tabular}{|c|c|c|c|}
\hline $\begin{array}{c}\text { Найменування } \\
\text { підходу }\end{array}$ & Сутність підходу & Перевага підходу & Недоліки підходу \\
\hline $\begin{array}{l}\text { Метод } \\
\text { паралельної } \\
\text { адаптації }\end{array}$ & $\begin{array}{l}\text { Стара і нова система } \\
\text { управління функціонують } \\
\text { паралельно, заміна } \\
\text { відбувається після повної } \\
\text { адаптації нових структур і } \\
\text { технологій менеджменту }\end{array}$ & $\begin{array}{l}\text { Відсутність опору, } \\
\text { можливість } \\
\text { коригувати нову } \\
\text { систему аудиту, не } \\
\text { втрачаючи } \\
\text { ефективності існуючої } \\
\text { системи менеджменту }\end{array}$ & $\begin{array}{l}\text { Збільшуються } \\
\text { витрати, дублюються } \\
\text { види робіт }\end{array}$ \\
\hline $\begin{array}{l}\text { Метод швидкої } \\
\text { функціональної } \\
\text { заміни }\end{array}$ & $\begin{array}{l}\text { Нова система змінює } \\
\text { існуючу }\end{array}$ & $\begin{array}{l}\text { Можливо швидке } \\
\text { впровадження системи } \\
\text { аудиту }\end{array}$ & $\begin{array}{l}\text { 3'являється небезпека } \\
\text { виникнення сильного } \\
\text { опору всередині } \\
\text { кооперативної } \\
\text { організації }\end{array}$ \\
\hline $\begin{array}{l}\text { Метод } \\
\text { пілотного } \\
\text { проекту }\end{array}$ & $\begin{array}{l}\text { В окремих функціональних } \\
\text { областях реалізуються } \\
\text { лише окремі функції і } \\
\text { елементи нової системи } \\
\text { менеджменту до повної } \\
\text { реструктуризації старої } \\
\text { системи }\end{array}$ & $\begin{array}{l}\text { Слабкий опір } \\
\text { проведеним змінам }\end{array}$ & $\begin{array}{l}\text { Небезпека затягнути } \\
\text { процес реорганізації, } \\
\text { що може призвести до } \\
\text { повного припинення } \\
\text { впровадження }\end{array}$ \\
\hline $\begin{array}{l}\text { Метод } \\
\text { поетапного } \\
\text { реформування } \\
\end{array}$ & $\begin{array}{l}\text { Чітке структурування } \\
\text { етапів і критеріїв переходу } \\
\text { з етапу на етап }\end{array}$ & $\begin{array}{l}\text { Поєднує перевага } \\
\text { перших двох підходів, } \\
\text { знижує опір змінам }\end{array}$ & $\begin{array}{l}\text { Висока вартість } \\
\text { проекту, значна } \\
\text { тривалість }\end{array}$ \\
\hline
\end{tabular}

Ажерело: складено авторами на основі $[1 ; 3 ; 7]$.

ння персоналом і інформаційна підтримка управлінських рішень в даній області для підвищення їх якості. Можна стверджувати, що цілі аудиту знаходяться в прямій залежності від цілей управління персоналом [1-7]. Основні завдання аудиту персоналу у міжнародних компаніях наведено в таблиці 1.

Аудит дозволяє визначити вплив процесів, що відбуваються в системі оцінки управлінського персоналу, на загальні характеристики діяльності міжнародної компанії. Він дозволяє використовувати дані аналізу відхилень у процесі оцінки на загальні результати діяльності міжнародної компанії [1-7]. Впровадження аудиту персоналу в міжнародних компаніях може здійснюватися $з$ використанням різних підходів (табл. 2).

Як було зазначено раніше, аудит персоналу - достатньо нове поняття в діяльності компаній, тому його впровадження може викликати опір стабільно працюючої системи аудиту [1-7]. Саме тому необхідно проаналізувати основні причини виникнення опору, і засоби, які дозволять їм протистояти (рис. 1).

Проектування системи аудиту персоналу в міжнародній компанії досить складний процес. Він здійснюється в декілька етапів (табл. 3).

Мережевий графік проекту аудиту персоналу в міжнародній компанії зображено на рисунку 2.

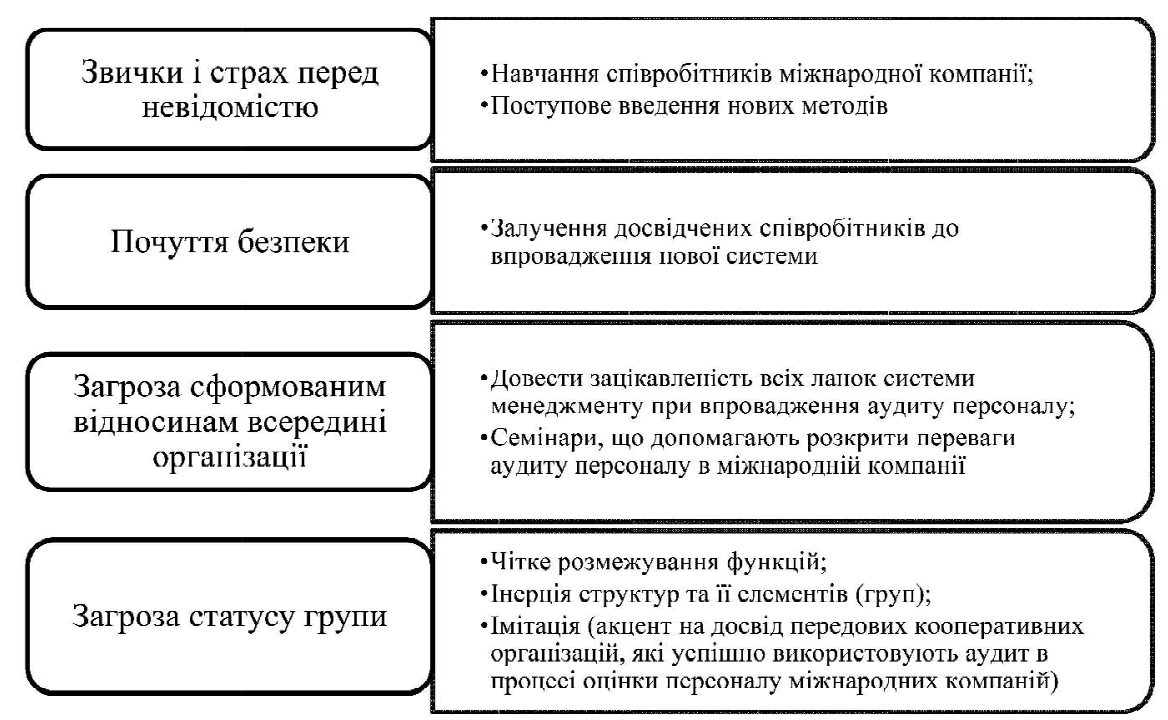

Рис. 1. Причини та методи подолання опору впровадження системи аудиту персоналу в міжнародних компаніях

Ажерело: складено авторами на основі [6]. 
Таблиця 3. Етапи аудиту персоналу в міжнародній компанії

\begin{tabular}{|c|c|c|}
\hline Етап & Зміст роботи & $\begin{array}{c}\text { Термін, } \\
\text { днів }\end{array}$ \\
\hline \multirow[t]{5}{*}{$\begin{array}{l}\text { Підготовчий } \\
\text { етап }\end{array}$} & $\begin{array}{l}\text { Оцінка умов проведення кадрового аудиту та розробка } \\
\text { стратегії в частині проведення аудиту }\end{array}$ & 2 \\
\hline & Розробка плану і робочих документів аудиту персоналу & 5 \\
\hline & Визначення вартості проведення аудиту персоналу & 1 \\
\hline & $\begin{array}{l}\text { Систематизація інформаційної бази, джерел отримання } \\
\text { аудиторських доказів }\end{array}$ & 1 \\
\hline & Перевірка дотримання чинного законодаства & 3 \\
\hline \multirow[t]{11}{*}{$\begin{array}{l}\text { Збір } \\
\text { інформації }\end{array}$} & $\begin{array}{l}\text { Аналіз облікового складу працівників за соціально- } \\
\text { демографічними характеристиками }\end{array}$ & 1 \\
\hline & $\begin{array}{l}\text { Аналіз структури кадрового складу за психологічними } \\
\text { характеристиками }\end{array}$ & 7 \\
\hline & $\begin{array}{l}\text { Оцінка укомплектованості кадрового складу в цілому і за } \\
\text { рівнями управління, включаючи оцінку забезпеченості } \\
\text { персоналом технологічного процесу }\end{array}$ & 2 \\
\hline & $\begin{array}{l}\text { Оцінка відповідності освітнього і професійно- } \\
\text { кваліфікаційного рівня персоналу, ступеня його } \\
\text { підготовленості вимогам виробничої діяльності }\end{array}$ & 3 \\
\hline & $\begin{array}{l}\text { Аналіз структури кадрового складу на відповідність } \\
\text { вимогам технології і класифікатору посад }\end{array}$ & 5 \\
\hline & Перевірка і аналіз даних про використання робочого часу & 6 \\
\hline & $\begin{array}{l}\text { Оцінка плинності кадрів і абсентеїзму, вивчення форм, } \\
\text { динаміки причин руху працівників, аналіз потоків } \\
\text { переміщень усередині організації, стану дисципліни праці }\end{array}$ & 3 \\
\hline & $\begin{array}{l}\text { Визначення в динаміці кількості працівників, зайнятих } \\
\text { працівників без відповідної кваліфікації }\end{array}$ & 6 \\
\hline & $\begin{array}{l}\text { Дослідження соціальних аспектів трудової діяльності } \\
\text { (мотивації праці, професійно-кваліфікаційного зростання, } \\
\text { сімейного стану, забезпеченості житлом та ін.) }\end{array}$ & 5 \\
\hline & $\begin{array}{l}\text { Збір та аналіз даних про рівень санітарно-гігієнічних } \\
\text { виробничих і побутових умов (стан робочих місць, місць } \\
\text { громадського харчування) }\end{array}$ & 8 \\
\hline & $\begin{array}{l}\text { Діагностика управлінського, інноваційного потенціалу } \\
\text { персоналу міжнародної компанії, його здатності до } \\
\text { навчання }\end{array}$ & 1 \\
\hline $\begin{array}{l}\text { Етап обробки } \\
\text { та аналізу } \\
\text { інформації }\end{array}$ & $\begin{array}{l}\text { Обробка та аналіз отриманої інформації. Отримана } \\
\text { інформація обробляється і формалізується у вигляді } \\
\text { таблиць, схем, графіків, діаграм (потім за розробленим } \\
\text { алгоритмом здійснюється аналіз і оцінка даних про } \\
\text { діяльність персоналу шляхом порівняння з іншими } \\
\text { аналогічними компаніями або науково обгрунтованими } \\
\text { нормами) }\end{array}$ & 15 \\
\hline \multirow[t]{2}{*}{$\begin{array}{l}\text { Заключний } \\
\text { етап }\end{array}$} & $\begin{array}{l}\text { Підготовка звіту про результати аудиторської перевірки, } \\
\text { формулюються висновки і рекомендації щодо раціоналізації } \\
\text { праці персоналу і вдосконаленню служби персоналу } \\
\text { міжнародної компанії }\end{array}$ & 10 \\
\hline & Надання звіту керівництву для аналізу та прийняття рішень & 0 \\
\hline
\end{tabular}

Ажерело: розроблено авторами.

Тривалість розробленого проекту згідно 3 мережевим графіком складе 47 днів. Отримані результати в процесі аудиту персоналу дозволять керівникам міжнародної компанії:

- оцінити ефективність діяльності співробітників;

- визначити внесок кадрової служби в досягнення цілей міжнародної компанії;

- вжити заходів щодо підвищення відповідальності працівників кадрової служби за реалізацією кадрових рішень;

- приймати прогресивні рішення, здійснювати нововведення в сфері управління людськими ресурсами;

- оцінити рівень функціонування системи

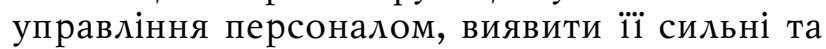
слабкі сторони, та удосконалити систему контролю.

\section{ВИСнОвКИ}

Кадровий аудит є потужним інструментом, який дозволяє керівництву міжнародної компанії виявити проблеми системи управління її персоналом, та дозволяє надати рекомендації для її поліпшення. Було проаналізовано систему управління персоналом міжнародної компанії з метою усунення таких негативних тенденцій в діяльності: плинність кадрів, скорочення середньооблікової чисельності працівників. Запропоновано ввести систему аудиту персоналу в діяльність міжнародної компанії. Було надано рекомендації, зазначено рекомендовані напрямки проведення аудиту персоналу в міжнародній компанії. Розроблений проект аудиту персоналу міжнародної компанії дозволить: 1) виявити проблемні місця в її кадровому забезпеченні, покращити мікроклімат всередині компанії; 2) удосконалити систему управлін- 


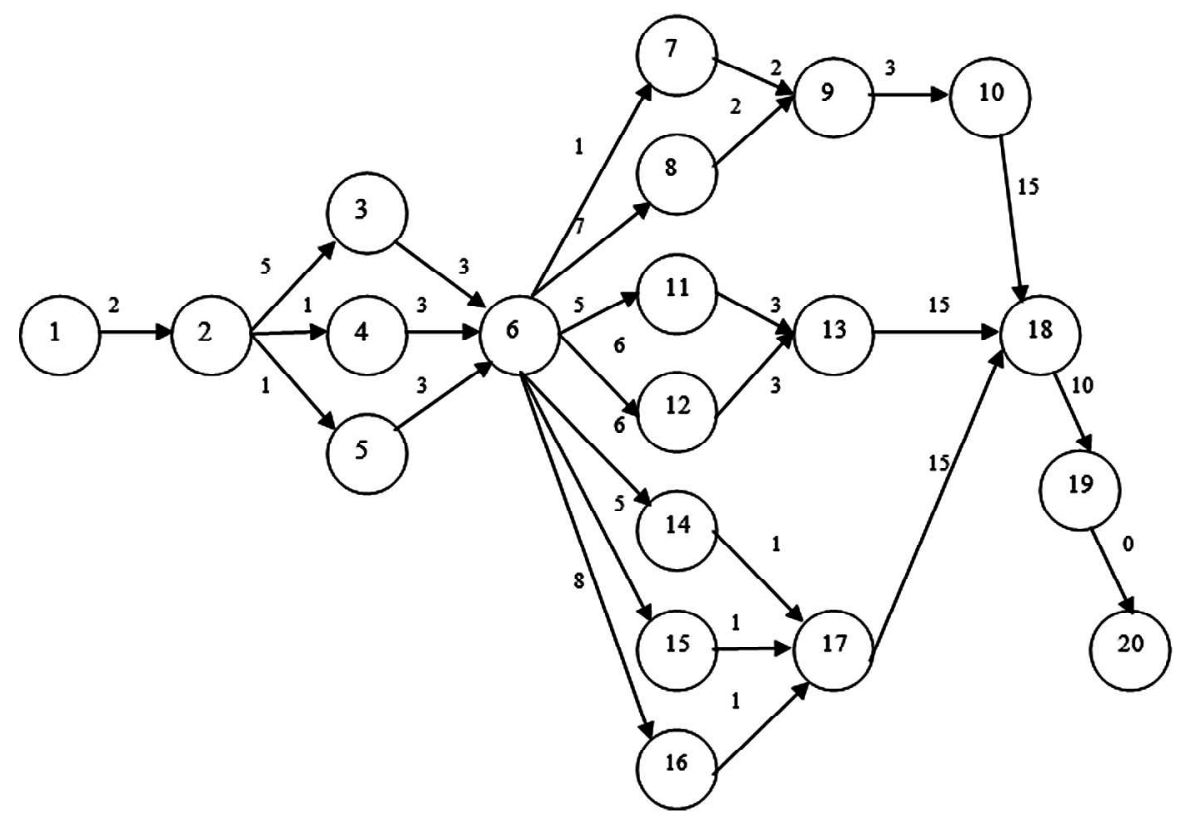

Рис. 2. Мережевий графік аудиту персоналу в міжнародній компанії

Ажерело: розроблено авторами.

ня персоналом; 3) керівництву своєчасно реагувати на проблеми 3 кадрами. Реалізація проекту аудиту персоналу міжнародної компанії передбачається в декілька етапів, а саме: підготовка до аудиту, проведення аналізу ключових показників, збір, узагальнення та обробка інформації, складання звіту та надання звіту з рекомендаціями керівництву міжнародної компанії.

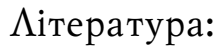

1. Назайкинский C.B. Роль HR-аналитики в принятии управленческих решений в организациях / С.В. Назайкинский, О.А. Седова // Вестник РГГУ. Серия "Экономика. Управление. Право". - 2017. — № 3 (9). - С. 9 - 19.

2. Назарова Г.В. Процедура здійснення аудиту персоналу на основі врахування можливих ризиків / Г.В. Назарова, О.С. Аебединська // Бізнес Інформ. - 2012. - № 8. - С. 117-120.

3. Совершенна I.О. Кадровий аудит як інструмент підвищення результативності менеджменту і розвитку організації / I.О. Совершенна // Економіка та управління підприємствами машинобудівної галузі: проблеми теорії та практики. - 2013. - № 1 (21). - С. 31-41.

4. Трофимов И.В. Аудит человеческих ресурсов как инструмент кадрового менеджмента / И.В.Трофимов // Российское предпринимательство. - 2012. - № 8. - С. 89-95.

5. Филина Ф.Н. Проведем аудит персонала / Ф.Н. Филина // Российский бухгалтер. 2007. - № 3. - C. 5.

6. Фріман Є.М. Організаційні засади аудиту персоналу при прийнятті кадрових рішень на підприємстві / Є.М. Фріман // Проблеми економіки. - 2012. - № 3. - С. $151-154$.

7. Хмелевський С.М. Аудит персоналу: неекономічні аспекти / С.М. Хмелевський // Глобальні та національні проблеми економіки. Мукачево, 2015. - № 3. - С. 466-470.

\section{References:}

1. Nazaykinskiy, S.V. and Sedova, O.L. (2017), "The role of HR-analysts in making managerial decisions in organizations", Vestnyk RHHU. Seryia "Ekonomyka. Upravlenye. Pravo", vol. 3, pp. 9-19.

2. Nazarova, G.V. and Lebedinska, O.S. (2012), "The procedure for conducting an audit of personnel based on the consideration of possible risks", Biznes Inform, vol. 8, pp. 117-120.

3. Sovershenna, I.O. (2013), "Personnel audit as a tool for improving the effectiveness of management and organization development", Ekonomika ta upravlinnia pidpryiemstvamy mashynobudivnoi haluzi: problemy teorii ta praktyky, vol. 1, pp. 31-41.

4. Trofimov, I.V. (2012), "Human resources audit as a personnel management tool", Rossijskoe predprinimatel'stvo, vol. 8, pp. 89-95.

5. Filina, F.N. (2007), "We will conduct an audit of the personnel", Rossijskij buhgalter, vol. 3, pp. 5 .

6. Friman, E.M. (2012), "Organizational fundamentals of personnel audit when making personnel decisions at the enterprise", Problemy ekonomiky, vol. 3, pp. 151-154.

7. Khmelevskyi, S.M. (2015), "Personnel Audit: Non-economic Aspects", Hlobal'ni ta natsional'ni problemy ekonomiky, vol. 3, pp. 466-470. Стаття надійшла до редакиії 20.02.2019 p. 